\title{
The Contemporary Delegitimization of (Medieval) History - and of the Traditional University Curriculum as a Whole
}

\begin{abstract}
The present delegitimization of History, and particularly of medieval History, is linked to the decline of the nation state, which ensured its own justification by referring to its own age and tradition. Nowaydays, economics, with its ahistorical logic, has become the ideology of a system in which multinational companies and transnational institutions have come to dominate. Seen in a broader perspective, the delegitimization of (medieval) History constitutes only one example of the loss of legitimacy that fundamental disciplines in general have suffered and that results from the fact that currently only monetary values are recognized as core values: advanced capitalism has succeeded in blending its ideology (i. e. its values), which is what enables it to reproduce itself, with the very mechanisms that form its core. As a corollary, the elite curriculum has shifted from fundamental to applied disciplines, leading to a qualitative increase in the recruitment of the latter; in addition, these applied disciplines have also been the main beneficiaries of the massification of higher education. This bifold increase, both qualitative and quantitative, has profoundly modified the relation of forces within the academic field and reversed it in favour of applied disciplines and the resulting social delegitimization has been translated into the academic delegitimization of the fundamental disciplines, of which the contemporary delegitimization of (medieval) History is only an illustration.
\end{abstract}

Keywords: Medieval Studies, tertiary education, France, social capital, capitalism, humanities, ideology

\section{Introduction: Why does a Discipline Question its Own Legitimacy?}

A discipline's capacity to ask why it exists has no intrinsic value. Instead, this value is inversely proportional to the capacity of the surrounding world to confront the

Note: Translated by Bruce L. VenARde (Pittsburgh) / Klaus OSChEmA (Bochum) / Chris JONES (Christchurch / NZ).

Julien Demade, chargé de recherches au CNRS, Laboratoire de médiévistique occidentale de Paris, 17 rue de la Sorbonne, 75005 Paris, France, demade@vjf.cnrs.fr 
discipline with this fundamental question. In other words, a discipline is strong if it can critically reflect on its own legitimacy when unchallenged, but also refuse to do so when its value is subject to external questioning. One might equally say that a discipline is strong when it can preserve its intellectual and scientific autonomy and that it functions well when it is able to question its function but not its existence.

As these initial observations demonstrate, it does not make much sense to ask the question of a discipline's relevance in an 'absolute' way. In order to discuss it in a meaningful way, we have to take into account the social context, implications, and effects of the individual discipline: it seems unlikely that a social organization, which an intellectual discipline certainly is, can ever really question its meaning without instrumentalizing that question. Therefore, it is appropriate, rather, to ask in concrete terms what social and intellectual conditions are likely to cause a discipline to question - or to allow others to question - its legitimacy.

It is hence necessary to set aside the question of value judgment in order to commence the analysis of observable social realities. Two different situations might bring a discipline to instrumentalize the question of its legitimacy. The first case occurs when the legitimacy of a discipline is challenged from the outside: the discipline finds it is called upon to justify itself. In reaction to such an exterior challenge, the question of legitimacy is addressed by the discipline only to avoid losing ground, to try to find a convincing answer - one that satisfies the 'outside' rather than itself. ${ }^{1}$ In the second case, a growing discipline seeks reasons that enable it to justify its expansion at the expense of other disciplines. These two situations refer not to the relative importance of a discipline but to its relative contraction or expansion - they concern trajectory, not standing. Thus, a very new discipline, one still developing and under-institutionalized, will create for itself a highly developed discourse of method to consolidate the positions it progressively gains (as in the case of Sociology in its Durkheimian phase). ${ }^{2}$ Conversely, a long-established and powerful discipline facing competition from newer and more dynamic disciplines will elaborate a self-justifying discourse.

It is clear that (medieval) History today finds itself in the second situation. The question, then, is not whether (medieval) History is now on the defensive; the question is how it has been forced into this position. Is the crisis only 'local', rooted in the growth of related disciplines? If so, this would affect only (medieval) History

1 See e. g. for the example of classical studies, Gilles Siouffi / Alain REy, De la nécessité du grec [ancien] et du latin, Paris 2016.

2 For the two successive moments in the establishment of Sociology in France, see Victor KaRADY, Stratégie de réussite et mode de faire-valoir de la sociologie chez les durkheimiens, in: Revue française de sociologie 20(1) (1979), pp. 49-82; John E. CRAIG, Sociology and Related Disciplines Between the Wars. Maurice Halbwachs and the Imperialism of the Durkheimians, in: Philippe BESNARD (ed.), The Sociological Domain: the Durkheimians and the Founding of French Sociology, Cambridge 1983, pp. 263-289. 
and be likely to preoccupy only (medieval) historians. Or is it instead a local effect of much larger transformations? If it is the latter, it is necessary to understand the situation of (medieval) History today by considering trends that appear to be very distant from it. ${ }^{3}$

\section{Loss of Ideological Utility}

In societies that relied on an ideology structured around the idea of the nation state, the study of history was self-evident: the study of history was an activity whose justification was so obvious one might say it was subconscious and therefore invisible. The image of the state, and still more that of the nation, was rooted in the past, which granted each state its legitimacy. In fact, the more distant that past, the better. It is revealing that, when history emerged as a modern academic discipline in France, at the beginning of the Third Republic (i. e. in the 1880s), most historians were trained medievalists ${ }^{4}$ who studied the history of France. In today's societies, however, the nation state has lost its status as the central component of ideology and has been replaced in this position by the transnational corporation. ${ }^{5}$ This new ideology is no longer structured according to its relationship with time, ${ }^{6}$ but instead

3 The following arguments mainly focus on the French case, with which I am most familiar due to my own training as a medievalist in France (and in Germany) and because I have spent most of my professional career in France (as well as in England and Spain). Wherever it seemed appropriate, however, I have chosen to point out similarities with other academic traditions and contexts.

4 Of those who held chairs in History at French universities in 1900, twenty-one had defended a dissertation in medieval History, ten in 'Modern History' (i. e. the period between the Middle Ages and the French Revolution), and eight in Ancient History, see Charles-Olivier CARBONNEL, Les professeurs d'histoire de l'enseignement supérieur en France au début du XX ${ }^{\mathrm{e}}$ siècle, in: ID. / Georges LIVET (eds.), Au berceau des Annales. Le milieu strasbourgeois: l'histoire en France au début du $\mathrm{XX}^{\mathrm{e}}$ siècle, Toulouse 1983, pp. 89-104. None of these professors had written his thesis on 'Contemporary History' (i. e. on a subject posterior to the French Revolution), because this period was still perceived as being a catalyst for national division rather than national unity. This becomes clear if one thinks of the - somewhat earlier - examples of Adolphe THIERS and François Guizot, who began as historians of the French Revolution and then went on to become influential and controversial politicians. The field was hence highly charged because of its clearly political dimension. 5 This demonstrates the efficiency of the present-day capitalist system. The structure that assures ideological reproduction has become identical with the structure that guarantees real domination, eliminating the possibility of contradiction between the two.

6 Therefore, it is not entirely correct to say that we live in a 'presentist' society, see François HARTOG, Regimes of Historicity. Presentism and Experiences of Time, trans. Saskia Brown, New York 2015 (French original Paris 2003), because this would imply a simple reversal of the once-dominant temporality. In fact, the relationship to time has, in a more essential way, been stripped of significance. HARTOG does not grasp this important point because he is exclusively interested in the uses of history, which prevents him from seeing the very change of history's status as 
tends towards timelessness. ${ }^{7}$ Ideology no longer finds its basis in the long term, but in a utilitarianism made eternal and natural through the sheer force of its logic.

If this loss of ideological utility is general to History, it is particularly notable in the case of medieval History. First, medieval History was once the dominant historical discipline because it performed the primary ideological function of telling the origin story of the nation state - be it the formation of the French territory from Hugh Capet to Joan of Arc, the creation of the German Empire with the Ottonians, the establishment of Spain's Catholic character with the so-called Reconquista, or the creation of the Swiss Confederacy, to name but a few examples. ${ }^{8}$ Secondly, if an ideological function remains for history, it has largely shifted to contemporary history ${ }^{9}$ - which certainly does not mean that medieval history has lost its ideological value entirely, ${ }^{10}$ but that this value is diminishing.

More generally, however, beyond the paradigmatic case of the disappearance of the immediate and central ideological function of history (medieval history in particular) lies the end of the indirect yet still central ideological function of intellectual activity in general. While intellectual life may once have served to signify - symbolically collective as well as individual value, ${ }^{11}$ today those functions are assumed by completely different social actors. These days, professional sports symbolize the

ideology. The matter is not merely a transformation in the functioning of history as ideology (that is, the periods on which it is based and the nature of the relationship it maintains to these periods), but more essentially, those transformations that affect the functioning of ideology and the diminished place history occupies in it.

7 In this regard, the evolution of Economics as a discipline, from its strongly historiographical origins (for example, in the work of Adam Smith, not to mention the subsequent dominance of the historische Schule in the second half of the 19th century) to its current interests in cognitive biology, is very revealing of much more general developments.

8 This general tendency does, of course, not preclude that other periods of history could, in specific countries, be the favored ones of the historicist ideology - for instance Roman antiquity in Italy.

9 There is no better indicator for this development than the evolution of secondary school curricula - if one accepts that these are by nature ideological -, which devote an ever more essential role to (ultra)contemporary history. But one might also think about what Germans at the end of the 20th century called, plain and simple, der Historikerstreit ("the historians' quarrel"), though the focus of this debate was entirely on 20th century history. It is equally striking that, when the Real Academia de la Historia published its monumental 50-volume "Diccionario Biográfico español", public debate arose only around figures linked to the Spanish civil war, see Tereixa CONSTENLA, La Real Academia cuenta su Historia, in: El País, 31 May 2011, online: https://elpais.com/diario/2011/05/31/cultura/ 1306792801_850215.html (last accessed 15/05/2019).

10 See, for example, the controversy surrounding Sylvain GouguenheIM, Aristote au Mont-SaintMichel. Les racines grecques de l'Europe chrétienne, Paris 2008, notably Philippe BüTTGEN et al. (eds.), Les Grecs, les Arabes et nous. Enquête sur l'islamophobie savante, Paris 2009; as well as, a little earlier, the extraordinary hype over the (putative) 1,500th anniversary of the baptism of Clovis, as organized by the very official "Comité pour la commémoration des origines" (created by the President of the French Republic - decree $n^{\circ}$ 96-180, 11/03/1996).

11 The first serving to mask internal contradictions, the second to justify domination. 
collective, and it is 'celebrities' (a group that notably includes athletes, but excludes intellectuals) ${ }^{12}$ who embody individual excellence: hence in France, for example, Zinedine Zidane and Johnny Hallyday have replaced Pasteur and Hugo in the pantheon of the venerated and honoured. ${ }^{13}$ The 'glitterati' have replaced the literati. Where governments and rulers once built universities to demonstrate their might and value (like Strasbourg for the German Second Reich and the Sorbonne for the French Third Republic), ${ }^{14}$ today they build stadiums, ${ }^{15}$ wasting immense sums in a process that is repeated every four years for the Olympic Games.

The loss of the ideological utility of intellectual activity in general and of (medieval) history in particular is all the more striking because of its context. The justificatory worth of ideological utility has diminished in favour of another kind of utility: the economic. Ideological value is now largely linked to economic value: a great soccer club is one that makes a lot of money, a great artist is one who has the largest revenues, a great university is one whose endowment is the largest ${ }^{16}$ and whose former students are the best paid once they start their professional career, and so on. Mature capitalism has managed to match its ideological values to monetary value, which is at the heart of its practical function. This coincidence is both a sign and a means of the efficiency attained by this mature system. For (medieval)

12 More precisely, the only 'intellectuals' who seek to belong to this group - and do so successfully - pay the price of getting out of touch with their originally academic milieu: hence only nonspecialists continue to consider figures like Bernard-Henri LÉvY or Claude ALLĖGRE as, respectively, philosopher and scientist.

13 "Johnny, it's Victor Hugo" reads a title in France's newspaper of reference, see Michel GuERRIN, Johnny, c'est Victor Hugo, in: Le Monde, 8 December 2017, online: http://www. lemonde.fr/idees/article/2017/12/08/les-champs-ce-sera-une-premiere-pour-un-chanteur-maisjohnny-c-est-victor-hugo_5226476_3232.html (last accessed 15/05/2019).

14 In Strasbourg, control over which was a central concern in the international politics of the Belle Époque, the whole cityscape constructed by the Hohenzollerns around the 'University Palace' was a counterpart to nothing less than the imperial palace. Each complex was built on the two opposites of the same monumental axis and served symbolically as the two essential elements, the one political and the other intellectual, of taking territory into possession. See John E. CRAIG, Scholarship and Nation Building. The Universities of Strasbourg and Alsatian Society (1870-1939), Chicago 1984.

15 This phenomenon, which took some time to become widespread and whose full effect is being felt only today, was the brainchild of the interwar fascists. Examples include the Stadio Benito Mussolini in Turin (1933) or, even more significant, the Reichssportfeld in Berlin (1936) and the Deutsches Stadion in Nuremberg (begun in 1937 but never completed). Both German stadiums were directly linked to properly political spaces (Maifeld, the parade ground in Berlin, and the Reichsparteitagsgelände complex in Nuremberg) and constituted one component of the urban axis structuring each city.

16 More generally, academia is currently turning into a system of "academic capitalism", in which, for universities, "achievement is measured, in the first instance, by the accumulation of capital, just as it is done for a capitalist business". See Richard MüNCH, Academic Capitalism, in: Oxford Research Encyclopedia of Politics, Oxford 2016, p. 12, online: DOI:10.1093/acrefore/9780190228637.013.15 (last accessed 15/05/2019). 
History, as for any other 'economically useless' discipline, the maturity of the system means these disciplines now stand at odds with the system, because it no longer really needs such disciplines to assure its reproduction. While it once simply used those disciplines ideologically in support of its own logic, the capitalist system, because it has matured, now aims to submit them directly to its own logic. It no longer allows them to survive, except to the extent that they respond to a sufficient demand for cultural formation and/or consumption ${ }^{17}$ - and it is precisely (medieval) history's loss of ideological function that brings about decreased demand. On the one hand, this loss means that (medieval) history ceases to be the object of major intellectual debates, which diverts the educated public from taking interest in it and lessens its cultural consumption. On the other hand, (medieval) history's loss of ideological function brings about a reduction in the state's emphasis on the educational value of the subject. (Medieval) history is no longer at the centre of national plans for ideological acculturation, and so reduced interest in (medieval) history brings with it shrinking numbers of secondary school teachers in this field. That decline, in turn, puts an end to students' primary job prospects and thereby generates a crisis in the recruitment of students to study (medieval) history.

\section{Divorce from the Elite Curriculum}

The recent decline in student numbers has first and foremost occurred in those 'useless disciplines' that have only an indirect ideological function, ${ }^{18}$ followed by those that once assumed a direct ideological function, including (medieval) History. As faculty numbers correlate to the number of students, it is, therefore, the very perpetuation of these fields that is at stake. However, it would be an error to think that this decline in student numbers is the most important indicator of the delegitimization of (medieval) History, along with other 'useless' disciplines. Because if we take the long view, what is most striking about student (and therefore faculty) numbers is in fact their extraordinary increase ${ }^{19}$ Consequently, should we choose to interpret

17 For English plans to stop subsidizing curricula in the Humanities, see Hannah RicHARDSON, Humanities to Lose English Universities Teaching Grant, in: BBC News, 26/10/2010, online: http:// www.bbc.com/news/education-11627843 (last accessed 15/05/2019).

18 For these disciplines, see Bernard ConverT, Les impasses de la démocratisation scolaire. Sur une prétendue crise des vocations scientifiques, Paris 2006.

19 While in 1952, there were 1,715 faculty members in faculties of arts and sciences in France, their number rose to 37,959 in 2005; the number of faculty in medieval History alone rose from 398 to 724 between 1986 and 2005. See Charles Soulí / Brice LE GALL, Massification, professionnalisation, et réforme du gouvernement des universités. Une actualisation du conflit des facultés en France, in: Charles Soullé / Christophe CHARLE (eds.), Les ravages de la modernisation universitaire en Europe, Paris 2007, tables 1, 2, and 4. 
these figures as a precise indicator of the value society attributes to disciplines, we would have to recognize a continuous long-term increase. The recent decline in numbers represents only a very minor correction in comparison to a long-term growth until the end of the twentieth century - an expansion that would have been unimaginable a hundred years ago.

Yet the fundamental indicator is not so much the quantitative but the qualitative evolution concerning the students who study the 'useless disciplines': this does not refer to the scholarly or intellectual quality of students, but rather to their social quality, which is characterized by their origins before their studies and by their future in the social arena after their studies. The observable development and its chronology are quite different from what has been described above for the quantitative dimension: the deterioration of the social status of the new recruits to the useless disciplines is quite significant and began earlier than the quantitative involution of the field. The extent of change that has affected the curriculum chosen by students of the social elite (and who are meant to reproduce it) is exemplified by the Hautes Études Commerciales (HEC) in Paris. Founded at the end of the nineteenth century as a second-rate school for 'Daddy's boys' who were unable to pass the baccalaureate exam (which explains the absence, at first, of an entrance exam), ${ }^{20}$ today this institution is the French school of higher education that has most alumni among the CEOs of the Fortune Global 500. ${ }^{21}$

In France, where since the nineteenth century technical schools have played an important role (although then clearly shared with universities) in the production of elites, ${ }^{22}$ the transfer of the elites' curriculum from the fundamental to the applied disciplines has been the least abrupt. In the Germany of Bildung, on the contrary, higher education was characterized by a social divide: on one side were old universities that, because they were devoted solely to traditional disciplines, were prestigious; on the other side, new institutions of higher education - the Technische Hochschulen - that, because they were restricted to applied disciplines,

20 The self-designated slang term for HEC students was "fistici" for "le fils est ici" ["the son is here"]. The HEC "was long considered a minor school [. . . offering to students whose birth destined them for social success a means to hide their academic failure”. See Pierre BourdiEU, La noblesse d'État: Grandes écoles et esprit de corps, Paris 1989, p. 236 n. 36 and p. 279; engl. trans. Pierre Bourdieu, The State Nobility. Elite Schools in the Field of Power, trans. Lauretta C. Clough, Cambridge 1996, pp. 168 n. 41 and p. 198.

21 Mines ParisTech, Classement international professionnel des établissements d'enseignement supérieur, enquête 2011, Paris 2011, p. 23, online: http://www.mines-paristech.fr/Donnees/data03/ 334-10.-Classements.pdf (last accessed 15/05/2019).

22 The Grandes Écoles were notably responsible for the education of civil servants and military officers, but their alumni also often held 'top-notch' positions in the private sector. 
were considered second rate. ${ }^{23}$ In the meantime, a radical change has taken place: today, the differentiation between the two types of institutions has not only been removed (since between the 1960s and the 1980s), but in addition the hierarchy of first and second rate has sometimes been reversed. ${ }^{24}$

The resulting question - which extends far beyond (medieval) History - is twofold: Why was it formerly considered necessary to include 'useless' disciplines as an essential element in the education of elites? And which changes in the structure of the elites and the economy enabled the disappearance of that necessity in favour of applied education $?^{25}$ Whatever the answer to these questions, a response that would identify as 'decline' what is in fact a sociological transformation, or that sees in it a development guided by values (in particular the loss of respect for useless knowledge) rather than sociological pressures, is unacceptable. This kind of answer would in fact lead to nothing other than the myth of a former 'golden age', one characterized by a beneficent, traditional national capitalism, in order to contrast it with its current, 'global', deviant incarnation. ${ }^{26}$ It is a myth, because it relies on an incorrect assumption: the fact that the classic curriculum of the elites lent a distinguished place to disciplines that were at once fundamental and, practically speaking, useless, does not enable us to assume that this must have been in recognition of the value of their very uselessness. Instead, beyond high-minded rhetorical flourishes concerning the value of the traditional curriculum lies a central fact: the mastery of fundamental knowledge served a specific purpose and it was hence not useless at all. The questions, then, are, what that 'usefulness of uselessness' could have been, at least in the education of elites, and why this 'usefulness of uselessness' has now vanished from

23 For comparison between higher education in Germany and France from 1850 to 1950, especially in terms of the history of ideas, see Fritz K. RINGER, Fields of Knowledge. French Academic Culture in Comparative Perspective, 1890-1920, Cambridge 1992.

24 In Germany, two of the first three universities which received the label of Eliteuniversität, created in 2006, were Technische Universitäten, while the traditional elite German universities of Heidelberg, Göttingen, and Berlin were excluded.

25 A medievalist is of course poorly equipped to respond to these questions, which instead call for a contemporary historian and sociologist specializing in education. Having myself done extensive research on both contemporary history and present-day society (see Julien DEMADE, Les embarras de Paris, ou l'illusion techniciste de la politique des déplacements, Paris 2015, and ID., Produire un fait scientifique. Beveridge et le Comité international d'histoire des prix, Paris 2018), I hope, however, that I might not be the worst-suited medievalist for such an endeavour.

26 To be convinced that such an argument is unacceptable, we need only note the impasses into which it drives us. It makes little sense to locate moral superiority in the larger role played by the fundamental disciplines in England or Germany of 1900 considering their manifestly inegalitarian and endogamous social structures, whose ties to the structures of higher education at the time are undeniable. See for instance, concerning the relationship between German academics and reactionary forces during and after the second Reich: Fritz K. RINGER, The Decline of the German Mandarins. The German Academic Community 1890-1933, Cambridge / MA 1969. 
the education of the elites (as it has, for that matter, from the education of other social groups)?

The explanation for the disappearance of 'useful uselessness' could, at first glance, be sought in the deepening division of labour, which, after affecting the dominated through 'scientific management', then reached the dominant, who have become specialists in clearly delineated operations of domination (financial services, marketing, human resources, and so on). Until the interwar period, the division of labour among the dominant remained largely limited to a division between engineers and all other members of the dominant group, with their less differentiated functions. The new delineations arose from the increased size of businesses through the process of concentration, something characteristic of the dynamics of the capitalist mode of production. Since, apart from the management of production, acts of domination were once general, this profile logically matched an equally general education. However, this explanation only shifts the problem: it is not obvious at all that this general education should have focussed on areas that had no link with business management, instead of providing insights into different activities (beyond the technical control of production) that were characteristic of it. ${ }^{27}$

In order to identify the reasons for the transformation of the elite curriculum, it thus seems more pertinent to address this basic transformation of mature capitalism: the replacement of capitalist owners with salaried managers at the top of businesses $^{28}$ - a transformation that just as well came about through the growth of the size of businesses, as concentration involved a dilution of capital. Because the capitalist owner assumed a general social function of domination, which was in no way limited to the management of his business, but potentially extended to all social fields, ${ }^{29}$ the specific competence of managing a business was only one element of

27 That was indeed the direction chosen around this time by the creators of the first Master of Business Administration (MBA) degree (at Harvard in 1908). But this kind of education, even though it was to have a great future in the curriculum of elites, took a long time to become widespread: as late as in 1930, there were still only three universities in the US offering this degree and it did not make its appearance in Europe until 1957. See Lars ENGWALL / Vera ZAMAGNI (eds.), Management Education in Historical Perspective, Manchester 1998.

28 Alfred Chandler, The Visible Hand. The Managerial Revolution in American Business, Cambridge / MA 1977; Hartmut KAELBLE, Long-term changes in the recruitment of the business elite: Germany compared to the U.S., Great Britain and France since the industrial revolution, in: Journal of Social History 13(3) (1980), pp. 404-423.

29 This was especially true in the political realm. Eugène $1^{\text {er }}$ Schneider, besides creating a family steel conglomerate, was a minister of Agriculture and Commerce, and a president of the French assembly, whilst in the 68 years between 1842 and 1910 one or another Schneider was elected as a deputy for 45 years; François de Wendel, besides managing a family mining and steel conglomerate, was a deputy and then a senator for more than thirty years; similar cases may be observed in Germany, for instance Hugo Stinnes. See for a general approach Jean GARRIGUES, Les patrons et la politique, de Schneider à Seillière, Paris 2002; for a case study see Jean-Noël JEANNENEY, François de Wendel en République. L'argent et le pouvoir (1914-1940), Paris 2004. Patronage, too, was an 
expertise among the many that were required of him. This array of demands was so varied that it could not be mastered by any one sort of practical education. The only solution was to rely on some sort of fundamental education that did not provide any specific expertise, but rather guaranteed a variety of general competences. ${ }^{30}$ For instance, graduates in History from Oxford between 1873 and 1929 "entered the highest levels of the civil, foreign, imperial and diplomatic services, politics, the Church, the military, law, journalism, letters, publishing, banking, economics, and university and secondary school teaching and administration; honours graduates in history were the product of a course of study intended explicitly to prepare them for important careers". ${ }^{31}$ Managers, on the other hand, based their legitimacy not only on the fact that they focussed exclusively on entrepreneurial matters (since the growth of the size of businesses left no time for other fields of action), ${ }^{32}$ but above all on the special expertise, vouched for by their academic credentials, that they had in running a business. The transformation of the curriculum of the elite thus indicates the transformation of the elite itself. Within the framework of internal struggles that resulted in the inversion of the dominant and dominated fractions, this was an essential instrument in the context of these struggles themselves.

The reasons why managers, in the field of domination as it was structured, stressed their special expertise (soon to be reinforced by academic credentials), should be clear: this was the only option they had when confronted with the generalist fashion in which capitalist owners carried out their functions. But how could this have turned into a winning strategy? Indeed, if the dominant fraction of the dominant class opted for a fundamental, and not 'applied' education, the reason lay not only in economic structures (that is, the limited size of businesses that

essential field of action for the reproduction of domination by means of justification, a field illustrated, for example, by the French branch of the Rothschilds or by Heinrich Thyssen. See Pauline Prevost-Marcilhacy, Les Rothschild. Une dynastie de mécènes en France, Paris 2016.

30 Another solution, adopted by textile manufacturers in the north of France, was also possible: all intellectual education was absent, replaced by on-the-job training from a very young age. Conversely, for steel manufacturers in eastern France, intellectual education, whether applied (notably through the School of Mines) or not, played a much more important role.

31 Reba SofFer, Nation, duty, character and confidence: history at Oxford, 1850-1914, in: Historical Journal 30(1) (1987), pp. 77-104, here p. 79.

32 It was not, of course, that capitalist power withdrew from them, but because more than ever before, it began to act via proxies within a framework of division of labour. The professionalization of politics (linked to particular types of higher education) went hand-in-hand with the professionalization of the management of businesses. For instance, whereas in the interwar period Maurice de Rothschild, first as deputy and then as a senator, directly fought for the interests of his bank in the political arena, after the Second World War this role fell to Georges Pompidou, a professional politician who had only briefly been director of the Rothschild bank (and hence to a man with a profile similar to that of another president of the French Republic: Emmanuel Macron). See Martine ORANGE, Rothschild, une banque au pouvoir, Paris 2012. 
allowed owners to invest in social fields other than the economic) but equally in the mechanisms of control over the reproduction of the elites themselves.

Between the second half of the nineteenth century and the first half of the twentieth, advanced study and membership of the dominant class went together to a considerable extent. ${ }^{33}$ Therefore, advanced study was not only, as today, a necessary condition for membership of the dominant class, but rather both necessary and sufficient at the same time. ${ }^{34}$ Hence control of access to this kind of study was vital for the reproduction of the dominant class. Those seeking social advancement tended to orient themselves toward practical education that allowed them to gain access to a profession, ${ }^{35}$ because fundamental education did not in itself allow them to secure a job while they lacked an appropriate network of (social) connections. Thus, it was very much the 'useless' character of fundamental education itself that made this field the preserve of elites: it could be used as an instrument to organize access to the dominant fraction of the dominant class by way of making it a simple matter of reproduction, whereas access to the dominated fraction of the dominant class was through applied education. Moreover, as the function of higher education consisted above all in social aggregation (since it was the sufficient condition of inclusion into the dominant class), studying fundamental disciplines could not be a problem because the function of education was not economic and did not aim at the acquisition of useful and practical expertise. Fundamental education, with the general competences it provided, was thus not only well adapted to the still little-differentiated exercise of power, but it facilitated cordoning off access to that power as well. ${ }^{36}$ Hence the

33 One should never forget that, for instance, in Germany in 1910 less than $1 \%$ of an age cohort entered university, and that in France in 1930 it still wasn't more than $2 \%$. See Fritz K. RINGER, Admission, in: Walter RÜEGG (ed.), A History of the University in Europe, vol. 3: Universities in the Nineteenth and Early Twentieth Centuries (1800-1945), Cambridge 2004, pp. 233-246, here pp. 238, 242.

34 England is peculiar in this respect, since it was rather secondary schooling, or more precisely the type of secondary schooling (the so-called public schools vs. the other forms of secondary schooling), that worked as the educational operator for belonging to the upper class. See W. D. RuBinstein, Education and the Social Origins of British Elites 1880-1970, in: Past \& Present 112(1) (1986), pp. 163-207, here pp. 174-175.

35 Just as well they tended to be oriented towards such practical disciplines: "In 1910 only 7 per cent of the students at English universities received grants, and these were mainly for technical training”. See Christophe CHARLE, Patterns, in: RÜEGG (note 33), pp. 33-80, here p. 63.

36 These two characteristics make clear that the 'useless' could not be 'useful', except when it concerned the production of members of the dominant fraction of the dominant class. Therefore, the usefulness of uselessness was an attribute strictly dependent on the social origin of students, which hence vanished with the transformation of this social background. This process thus undermined the legitimacy of fundamental disciplines, because the 'useless' became 'useless' indeed. 
fact that for instance at the university of Glasgow in 1913-1914 "as many as 79 percent of students were taking the general degree course, with its broad training"; even in the interwar period no less than 80 per cent of Oxford's students were still in the arts faculties. ${ }^{37}$

These observations should make clear that the success of the managers' strategy for joining the dominant fraction of the dominant class by highlighting their applied education was not a foregone conclusion. Of course, it relied on special expertise that was better and better calibrated to the growth in size - and thus in complexity - of businesses. But at the same time, the strategy made control of the reproduction of elites through higher education more difficult, since applied education allowed less economic segregation of new members of the elite. This difficulty was all the greater because advanced education continued to become more widely available, and thus could not function in itself as a sufficient means to control access to the dominant class. Therefore, conversely to the managers' strategy, it would have been necessary to maintain the privilege of fundamental education, which was the only branch of education that could ensure the perpetuation of the identical reproduction of elites through higher education, despite the drive to mass higher education.

Yet that is not at all what happened. The drive to mass higher education succeeded not only through some applied disciplines (in France, the Administration Économique et Sociale, the Instituts Universitaires de Technologie, and so forth). At the same time, the 'useless' disciplines became just as well characterized by considerable numbers of newcomers of middle-class origins and mediocre social prospects, whereas the elites' heirs henceforth focussed on certain applied disciplines from which the newcomers now found themselves excluded.

The transformation of the elites' curriculum was thus motivated by a more imperative reason than just the modification of business structures or the control of the reproduction of elites. That prevailing reason was the necessary correspondence between the elite curriculum on the one hand and the central figure of ideology on the other. Only on the basis of this correspondence could the dominant position of the elites be justified and thus made acceptable to the dominated. On the other hand, any fundamental lack of correspondence, that is, when the dominant form of ideology corresponds only to the curriculum of the dominated, would lead to a disruption of power relations: it would legitimate the dominated and therefore delegitimize domination, which would thus become impossible. ${ }^{38}$

37 Gillian Sutherland, Education, in: F. M. L. THompson (ed.), The Cambridge Social History of Britain 1750-1950, vol. 3: Social Agencies and Institutions, Cambridge 1990, pp. 119-170, here pp. $158,167$.

38 We must not confuse this fundamental imbalance with a secondary form of imbalance as it occurs when the curriculum of elites is no longer adapted to the dominant form of ideology. The curriculum adapted to this new form becomes the monopoly of another elite, hence this secondary form of a lack of correspondence results only in the substitution of one elite for another. It does not 
As I have already said, mature capitalism, in contrast to its earlier stages, is characterized by the convergence of the social function of reproduction and the ideology that ensures the possibility of that reproduction. We could sum this up as 'the monetarization of ideology': monetary value has become paramount for all other types of social values. As a result, the curriculum of elites necessarily had to reorient itself toward the applied study of the techniques of capitalist domination (management, marketing, law, public relations, economics, and so on), since they are the means of producing monetary value. The curricular reorientation had the additional advantage of reinforcing the elite's practical capacity to master the economic system. The outcome was thus doubly advantageous, both ideologically and practically, which makes it characteristic of mature capitalism. In this way, the rule of practice over theory was established, which relegates the latter - and along with it the fundamental disciplines and academic institutions ${ }^{39}$ that exemplify it - to the dominated fraction of the academic field. Thus the 'democratization' of student and faculty recruitment in these fields, meaning the negative change in their social attributes alongside those of these newly diminished disciplines, became possible as well as necessary.

Applied disciplines and training have benefited not only from the reorientation of elite curriculum towards them (qualitative advance) but also from the extraordinary rise in their numbers (quantitative advance). This is due to the drive to mass higher education - preferentially concentrated on applied disciplines and training -, that is, the process by which advanced teaching began to have as its chief function the production not of the dominant but the dominated, specifically the dominant fraction of the dominated, that is the middle management. ${ }^{40}$ This transformation is owed to the increase in labour productivity, which prompted a double transfer of labour formerly devoted to physical production: on the one

question the structures of domination, only their means of realization, as in the case of the transition from capitalist owners to managers.

39 There has indeed been, within the academic field stricto sensu (French as well as foreign), a change in the balance of power in favour of applied education. Emblematic in this regard is the case of the University of Paris-Dauphine (specializing in Business 'Sciences', which are simply techniques), which at its origin in 1971 was not even designed as a fully functioning university and which obtained the highest-ranking status of Grande École in 2014. In just over forty years, its trajectory has thus led it from the most dominated fraction of the academic field to the most dominant fraction. See http:// www.dauphine.fr/fr/universite/dauphine-historique.html (last accessed 15/05/2019).

40 The upheaval in the function of advanced education can be conveniently dated to the academic crisis brought about by it around 1968 in Germany, Italy, and the US as well as in France, see Pierre BourdiEu, Homo Academicus, Cambridge 1990, ch. 5. Between 1960 and 1970, student enrolment went from 240,000 to 695,000 in France, and from 268,000 to 682,000 in Italy, see Guy NEAVE, Patterns, in: Walter RÜEGG (ed.), A History of the University in Europe, vol. 4: Universities since 1945, Cambridge 2011, pp. 31-69, here p. 42. For the creation of middle management as a new social group, see Luc BolTANSKI, The Making of a Class. Cadres in French Society, Cambridge 1987. 
hand to the design and control of that physical production, and on the other hand to the creation of the intangible value of physical production through marketing and branding.

This transfer made higher education the production site for, first, the domination wielded over the dominated (as the dominated internalized and reproduced this domination) and secondly, the value of the dominated to the system of domination (ensuring that they fit into the process of production in a way profitable for the dominant). Both productions are ideally ensured by applied disciplines and training. They now transmit the very ideology of mature capitalism, justifying the domination over the dominated. ${ }^{41}$ Additionally, they strengthen the effectiveness of the workforce by making it incorporate techniques likely to ensure the enlarged practical reproduction of the system. The consequence of this change is that fundamental disciplines have suffered not only a qualitative decline in their recruitment, but also a relative quantitative decline, because within the framework of the drive to mass higher education their numbers have risen less rapidly. In France, for example, although between 1986 and 2005 faculty numbers rose considerably in French Literature (+31\%), Theoretical Chemistry (+54\%), Mathematics (+75\%), and Ancient and Medieval History (+82\%), the increase was much greater in Mechanical Engineering (+188 \%), Business (+280 \%), Computer Science (+291\%), and Communications $(+399 \%){ }^{42}$ The numbers of students as well as of faculty in the fundamental disciplines certainly rose, giving these disciplines a quantitative importance unimaginable at the time their social value was most unanimously acknowledged. That being the case, the decline of these disciplines, as clearly (if not easily perceptibly) indicated by the qualitative and (relative) quantitative decline in recruitment, could long go unrecognized.

41 If 'applied disciplines' nowadays are the privileged way to inculcate ideology among the dominated, this is by no means due to any inherent property they possess, but rather is owed to their congruence with the current stage of the development of capitalism. Hence it is completely futile to cultivate essentialist ideas that irreducibly contrast 'fundamental disciplines', which would further reflexivity and therefore emancipation, with 'applied disciplines', which would accustom their students to the passive application of unquestioned laws and therefore alienation. It is undeniable that, at present, the capacity for protest is concentrated among both students and instructors of the fundamental disciplines, incompatible as they are with the reproduction of the ideology of the capitalist system in its mature stage. In an earlier stage of capitalism, however, members of the fundamental disciplines were in harmony with the dominant ideology; the most devoted acolytes of the ruling order were among their representative members. An excellent illustration is the behaviour of German students and scholars under the Nazi regime. For the particular case of medieval History and more specifically medievalists studying rural areas, see Julien DEMADE, The Medieval Countryside in German-language Historiography since the 1930s, in: Isabel ALFONSO ANTON (ed.), The Rural History of Medieval European Societies. Trends and Perspectives (The Medieval Countryside 1), Turnhout 2007, pp. 173-206. Conversely, that great monument to applied disciplines, the Encyclopédie of Diderot and d'Alembert, was a protest against the last stage of the ecclesio-feudal system.

42 See Soulié / Le GALL (note 19), tables 3, 4, and 5. 
All in all, the lowering of the (social) quality of recruits to the fundamental disciplines has made possible their growth in absolute terms. This corresponds to a crucial transformation in the reasons which determine the students' decision to study those fundamental disciplines. Far from continuing to be chosen, as they formerly were, by heirs to the elites for the exclusively general skills they provided, the fundamental disciplines were now chosen by the new recruits for their ability to provide jobs in secondary education, which expanded quantitatively alongside tertiary education. Students of fundamental disciplines, because they were now new recruits to higher education, gravitated toward them precisely because of the immediate job prospects they offered - and ultimately behaved towards them just as their predecessors once did towards applied disciplines. Thus, the fundamental disciplines became, in the use students made of them, a 'practical' education like any other. Its place in the hierarchy of instruction corresponds to the place of the profession for which it prepares its students in the hierarchy of professions - a very low place, as it turns out, because it is not tied to an economic function.

As a consequence, the qualitative transformation in students' objectives made possible the absolute quantitative increase in their numbers - all the while aggravating the qualitative social decline of recruitment to the fundamental disciplines, as this decline was due not only to the disappearance of the heirs (a negative factor of deterioration) but also (and more so) to the massive influx of new recruits (a positive factor of deterioration). The combination of this absolute qualitative decrease and the relative quantitative decrease produced a twofold delegitimization of the fundamental disciplines ${ }^{43}$ and ended up bringing about, today, a quantitative decline in terms not only relative but indeed absolute - first of students, then of faculty -, which added a supplementary source of delegitimization. The decline will hence probably be both long and steep, leaving the academic field turned upside

43 In addition to the fundamental delegitimization linked to the loss of a central ideological role, loss which in itself brought about the two subsequent delegitimizations under discussion here. Regarding the latter, the essential factor is certainly qualitative decline, the hierarchy of disciplines being directly linked to the place of their students and faculty in the social hierarchy. Nevertheless, the relative quantitative decline is far from being without effect - not so much on the general perception of the fundamental disciplines, but rather on their place within the academic field: the transformation of the relative importance of disciplines brings about modifications to the power relations inside as well as between faculties. Seen from this perspective, applied disciplines are clearly in the ascendant: to the detriment of the fundamental disciplines, they now exceed the former in terms of numbers, position, and respectability (all of which were formerly privileges of the latter), and generally exercise increasing influence over the policy choices of each university to their own benefit. In France, for instance, in 1986 the number of university students in Geography was $15 \%$ higher than the number in Business; in 2005 it was $50 \%$ lower. The same goes for Philosophy versus 'Information and Communications Science': in the mid-1980s, there were twoand-a-half times more students in Philosophy than in the newer discipline; by 2005 that number had fallen to less than $40 \%$ of the number enrolled in 'Information and Communications Science', see SoUlí̂ / LE GALL (note 19), tables 3 and 4. 
down because it will give absolute domination to applied training to the detriment of fundamental disciplines. Such, at least, is the lesson to be derived from the American example, which one can rightly consider, as the most advanced capitalist system, a precursor of changes that Western Europe frequently faithfully reproduces after some delay. Based on a theoretical index of 100 as baseline for 1970, the number of masters' degrees awarded in the USA declined, 30 years later, to 59 in Mathematics, 80 in Physical Sciences, 83 in Social Sciences and History, while it exploded to 401 in Law, 448 in Business, and 759 in Medicine. ${ }^{44}$ The drive to mass higher education has hence been, for the fundamental disciplines, nothing but a temporary illusion.

\section{Conclusion}

The fundamental disciplines lost legitimacy as ideological reproducers of the social system, a role which was especially important in the case of (medieval) History. These same disciplines also lost the role they played in the reproduction of the dominant class, which reinforced their delegitimization, the academic hierarchy being based on the social position of students. This double delegitimization, in the sense of a twofold loss of function, ended up bringing about today's drop in recruitment - after a temporary explosion of numbers that did nothing but reinforce the illegitimacy of student recruitment and that finally was nothing more than a flash in the pan. The background and the effects of this decline in recruitment should prevent us from thinking that we might be able to compensate for the loss of the fundamental disciplines' ideological function by claiming some kind of economic justification that could be linked to student 'demand'. The fundamental disciplines, which have lost the traditional foundations of their social utility, have proved to be incapable of substituting a different form of social utility.

Could one thus imagine a better moment to ask if the justification and the meaning of intellectual disciplines (but also more broadly of any action) could not derive from something other than social utility? Or, perhaps even more importantly, are there not other forms of legitimization that have nothing to do with the reproduction of social forms whose own legitimacy it is perfectly justifiable to question ${ }^{45}$

44 CONVERT (note 18), p. 71, table 13.

45 For reflections of this sort carried out with exclusive reference to (medieval) History, see Julien DEMADE, L'histoire (médiévale) peut-elle exciper d'une utilité intellectuelle qui lui soit spécifique?, in: Didier MÉHu / Néri de BaRRos Almeida / Marcelo CÂNDIDO DA Silva (eds.), Pourquoi étudier le Moyen Âge? Les médiévistes face aux usages sociaux du passé (Histoire ancienne et médiévale 114), Paris 2012, pp. 15-60. 